\title{
Formulation and evaluation of peel-off gel mask from whole milk yogurt and seaweed (Eucheuma cottonii) as antioxidants sources
}

\begin{abstract}
Skin needs care to avoid premature aging. One of them is treatment with natural-based masks that have antioxidant activity. This study aims to see the antioxidant potential of various concentrations of natural ingredients yogurt and seaweed Eucheuma cottonii as active substances in the manufacture of peel-off gel masks. The method used in this research is the fermentation method for making yogurt, stability test for 28 days at room temperature and antioxidant test with DPPH, to determine the antioxidant power of the five variations of the mask formulation by measuring the IC50 value obtained by reading the absorbance with UV Spectrophotometer -Vis. The results obtained from this study are Formula 4 (F4) has the lowest IC50 value of 18.647 where the IC50 value can be categorized as an antioxidant with very strong strength. The results of the stability test can be stated that the preparation remains stable at room temperature storage for 28 days. The conclusion from the results of this study is that F4 (yogurt: seaweed 1:1) has the highest antioxidant activity strength among other formulations.
\end{abstract}

Volume 9 Issue 4 - 202 I

Ira Adiyati Rum, Husnul W Suherman, Idar

Faculty of Pharmacy, Bhakti Kencana University, Indonesia

Correspondence: Ira Adiyati Rum, Faculty of Pharmacy, Bhakti Kencana University, Indonesia, Tel +62853 I6588844,

Email ira.adiyati@bku.ac.id

Received: June 29, 2021 | Published: July 22, 202 I

Keywords: antioxidant, Eucheuma cottonii seaweed, fermentation, peel-off gel mask, yogurt

\section{Introduction}

Skin is the outermost organ in the human body. The skin is an organ that functions as a protector of internal organs from exposure to external materials, biological, physical and chemical substances. One of the external exposures that are harmful to the skin is sun exposure. Exposure to sunlight that emits ultraviolet (UV) radiation can cause black spots on the face and make the face look dull. ${ }^{1}$ Therefore, it is necessary to take care of facial skin to overcome this, one of which is taking care of facial skin by regularly using face masks.

Face masks are one of the cosmetics for skin care that are generally often used by women so that the appearance of facial skin becomes healthier and more beautiful. The benefits of face masks include cleaning the pores, moisturizing and nourishing facial skin. ${ }^{2}$ Peel-off gel masks have the advantage of being practical, because they are easy to peel off and lift like an elastic membrane. As time goes by, currently the demand for the use of natural ingredients as active substances in the manufacture of cosmetic products is growing rapidly. ${ }^{3}$ Therefore, in this study, a peel-off gel mask was made as a skin care product with natural active substances, namely a combination of cow's milk yogurt and seaweed.

Yogurt is a processed product of fermented milk that has excellent nutritional value for the human body. Milk is one of the foodstuffs that have very high nutritional value because milk contains many nutrients including lactose, fat, protein, various vitamins, and minerals. Yogurt has a characteristic sour taste produced by the bacteria Lactobacillus bulgaricus and Streptococcus thermophillus. Yogurt acts as a source of calcium, vitamin D and contains protein that is very good for the skin. Yogurt also contains lactic acid and alpha hydroxy acid (AHA) where this AHA acts to help moisturize and remove dead skin cells which in turn can make facial skin look smoother and brighter. ${ }^{4}$
In addition to yogurt, the natural ingredient used as an active ingredient in making this mask is seaweed. Seaweed is believed to have benefits for beauty because it contains several vitamins and minerals which are certainly needed by the skin. Seaweed also acts as an antioxidant for the skin because it contains vitamin C. ${ }^{5}$ Therefore the combination of yogurt and seaweed is very good. In addition, it is packaged in a peel-off gel mask preparation which can be said to be practical in its use. In addition, this study also seeks to enrich yogurtderived products, because so far yogurt has only been used as food, not yet widely used as an alternative to antioxidant basic ingredients for cosmetic preparations.

The masks formulated in this study are also made from natural ingredients which are certainly not harmful to facial skin. Given that many chemicals that make facial skin experience several skin problems, for example, irritate and cause premature aging. The combination of natural ingredients from yogurt and seaweed face masks can also brighten the face and reduce dark spots on the face by $20 \%$ every week. $^{3}$

Therefore, this study aims to understand the potential antioxidant of variations concentration of yoghurt and seaweed for peel off masks preparation. Also to know whether the preparations is comfortable/not to skin and whether it fulfills pharmaceutical requirements.

\section{Material and methods}

Materials: Fresh whole cow milk, commercial yoghurt plain starter, pan, beaker glass PYREX JAPAN, incubator MEMMERT GERMANY, seaweed, PVA (Polivinil alcohol), HPMC (Hydroxypropyl Methylcellulose), propilenglikol, DMDM hydantoin, aquadest, $\mathrm{pH}$ meter METLER TOLEDO Switzerland, viscometer BROOKFIELD USA, stopwatch, methanol PA, Spectrophotometer 
UV Vis ThermoFisher Scientific, USA DPPH (2,2-difenil-1pikrilhidrazil) solutions.

\section{Research location and time}

The research was carried out in two places, namely the Ayra Mini Yogurt Laboratory in the Pasir Impun area as a place to produce yogurt and the formulation until the evaluation test was carried out at the Pharmacy Laboratory of Bhakti Kencana University Bandung. The time of the yogurt making research was carried out in November 2020. The implementation of the formulation and evaluation test in February - May 2021.

\section{Method of collecting data}

This research is an experimental research in a laboratory which has been passed through several stages, including:

\section{Yogurt production}

Making yogurt is done using the fermentation method from fresh cow's milk obtained from cattle farmers in the Ciporeat area, East Bandung. The yogurt produced is formed from four types of bacteria, namely Lactobacillus bulgaricus, Streptococcus thermophilus, Lactobacillus acidophilus and Bifidobacterium. Fermentation is carried out through an incubation process for approximately 5-9 h at a temperature of $40^{\circ} \mathrm{C}$ the following temperature is the optimal temperature at which bacteria can grow. ${ }^{6}$

\section{Seaweed porridge (Eucheuma cottonii) production}

Seaweed of fresh Eucheuma cottonii type is made into a slurry preparation before being mixed with the peel-off gel mask formulation. The manufacture of seaweed slurry is done by mixing Seaweed with Aquades (1:1) then crushed (Luthfiyana et al., 2019).

\section{Peel-off gel mask production}

The peel-off gel mask is made by mixing several ingredients that have been prepared. Five variants of the formulation were made, with a comparison between yogurt and seaweed. The first formula (F1) is yogurt and seaweed (4:0). The second formula (F2) is yogurt and seaweed $(0: 4)$. The third formula $(\mathrm{F} 3)$ is yogurt and seaweed $(3: 1)$. The fourth formula (F4) is yogurt and seaweed (2:2). The fifth formula (F5) is yogurt and seaweed (1:3). In this process, polyvinyl alcohol (PVA) was used as a film-forming agent, HPMC (hydroxypropyl methyl cellulose) as a gel base, DMDM Hydantoin as a preservative, propylene glycol as a humectant, and aquades as a solvent.

\section{Antioxidant test}

Antioxidant tests were carried out on five samples, namely, antioxidant testing of yogurt and seaweed peel-off gel mask preparations in each formulation (F1, F2, F3, F4 and F5). In this antioxidant testing was carried out by the DPPH method. In this DPPH antioxidant test method with the principle of measuring free radical scavenging power by antioxidants. The levels and properties of antioxidants were determined by measuring $\mathrm{IC}_{50}$. $\mathrm{IC}_{50}$ (Inhibitory Concentration 50) is a parameter of the effectiveness of the sample in counteracting free radicals in the DPPH method. $\mathrm{IC}_{50}$ is also defined as a concentration that can reduce $50 \%$ of free radicals from $\mathrm{DPPH}^{7}$

\section{Consumer preference test (hedonic test)}

This consumer acceptance test was conducted with the aim of knowing the level of preference and convenience of using this peeloff yogurt and seaweed gel mask. This test will be carried out on 20 female or male respondents with an age range of 17-40 years and then a questionnaire will be conducted from the results of using this peeloff gel mask product.

\section{Results}

Figure $1 \& 2$, Charts $1 \& 2$, Tables 1-5.

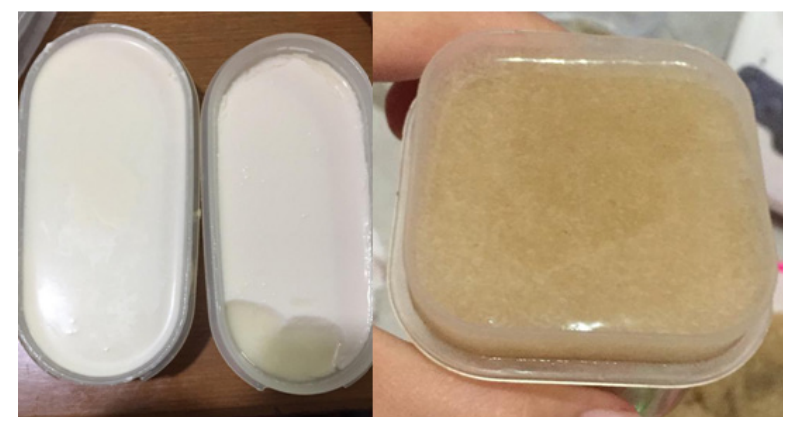

Figure I Yogurt from whole milk and Jelly from seaweed Eucheuma cottonii.

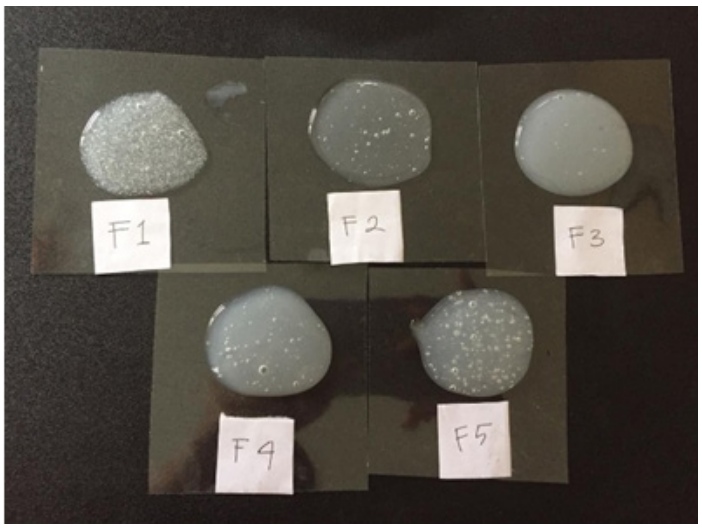

Figure 2 Peel off gel mask with 5 formulations.

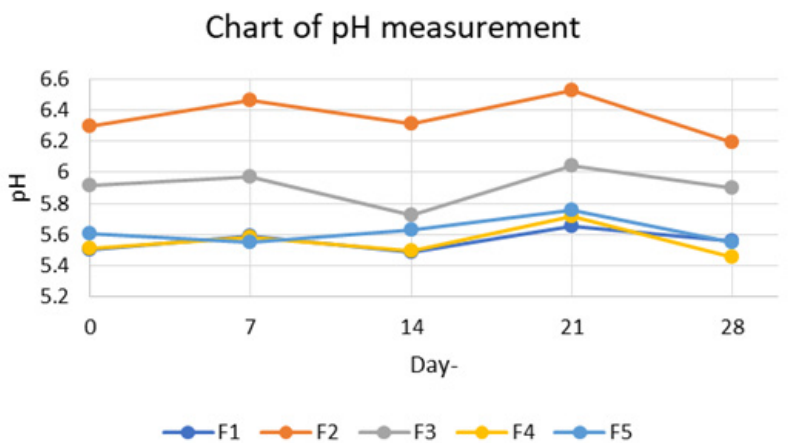

Chart I pH measurements of peel off gel mask.

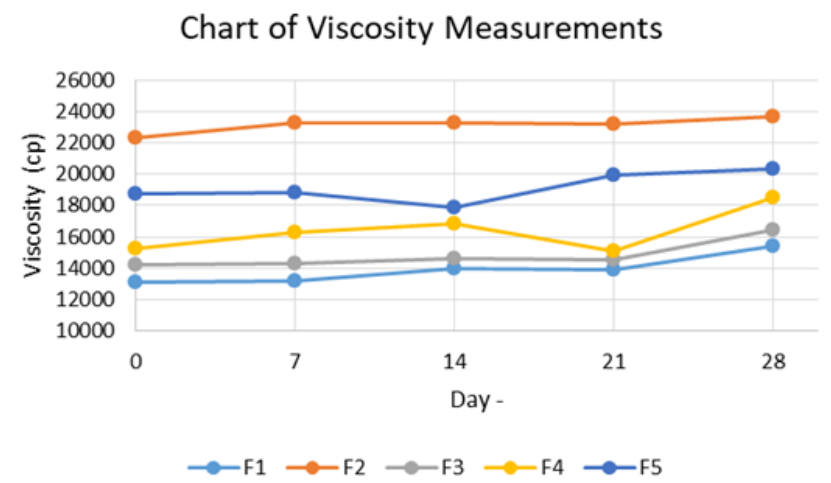

Chart 2 Viscosity Measurements of peel off gel mask. 
Table I Result optimization for basic formulation

$\begin{array}{ll}\text { Polivinil Alkohol } & 12 \% \\ \text { Polivinil Pirolidon } & 1 \% \\ \text { Carbopol } 940 & 0.5 \% \\ \text { Propilenglikol } & 2 \% \\ \text { Etanol } 95 \% & 17 \mathrm{ml} \\ \text { Tri-etanolamin } & 7 \text { tetes } \\ \text { DMDM Hydantoin } & 0.6 \% \\ \text { Aquadest ad } & 100 \text { gram }\end{array}$

Table 2 Masker gel peel-off formulation

\begin{tabular}{|c|c|c|c|c|c|}
\hline \multirow{2}{*}{ Ingredients } & \multicolumn{5}{|c|}{ Formula (\%) } \\
\hline & FI & $\mathbf{F 2}$ & F3 & F4 & F5 \\
\hline Yogurt & 4 & - & 3 & 2 & I \\
\hline Seaweed & - & 4 & I & 2 & 3 \\
\hline PVA & 12 & 12 & 12 & 12 & 12 \\
\hline PVP & 1 & 1 & I & 1 & I \\
\hline Carbopol 940 & 0.5 & 0.5 & 0.5 & 0.5 & 0.5 \\
\hline Propilenglikol & 2 & 2 & 2 & 2 & 2 \\
\hline Etanol 95\% & $17 \mathrm{ml}$ & $17 \mathrm{ml}$ & $17 \mathrm{ml}$ & $17 \mathrm{ml}$ & $17 \mathrm{ml}$ \\
\hline Tri-etanolamin & 7 drops & 7 drops & 7 drops & 7 drops & $\begin{array}{l}7 \\
\text { drops }\end{array}$ \\
\hline $\begin{array}{l}\text { DMDM } \\
\text { Hydantoin }\end{array}$ & 0.6 & 0.6 & 0.6 & 0.6 & 0.6 \\
\hline
\end{tabular}

Table 3 Summary of mask physical evaluations

\begin{tabular}{llll}
\hline No. & Parameter & $\begin{array}{l}\text { Fullfill } \\
\text { pharmaceutical } \\
\text { requirements }\end{array}$ & $\begin{array}{l}\text { Do not fill } \\
\text { pharmaceutical } \\
\text { requirements }\end{array}$ \\
\hline I & pH & $\checkmark$ & \\
2 & Viscosity & $\checkmark$ & \\
3 & Spreadability & $\checkmark$ & \\
4 & Drying time & $\checkmark$ &
\end{tabular}

Table 4 Summary of antioxidant level

\begin{tabular}{lll}
\hline Sample & IC $_{50}$ value & $\begin{array}{l}\text { Antioxidant } \\
\text { Category }\end{array}$ \\
\hline Ascorbic Acid & 3.876 & Very high \\
Yogurt & 15.548 & Very high \\
Seaweed & 11.971 & Very high \\
Formula I mask & 79.422 & High \\
Formula 2 mask & 5.110 & High \\
Formula 3 mask & 10.803 & Mid \\
Formula 4 mask & 18.647 & Very High \\
Formula 5 mask & 22.477 & Very High \\
\hline
\end{tabular}

Table 5 Summary of gel mask physical evaluations

\begin{tabular}{llll}
\hline No. & Parameter & $\begin{array}{l}\text { Fullfill } \\
\text { pharmaceutical } \\
\text { requirements }\end{array}$ & $\begin{array}{l}\text { Do not fill } \\
\text { pharmaceutical } \\
\text { requirements }\end{array}$ \\
\hline $\mathrm{I}$ & $\mathrm{pH}$ & $\checkmark$ & \\
2 & Viscosity & $\checkmark$ & \\
3 & Spreadability & $\checkmark$ & \\
4 & Drying time & $\checkmark$ & \\
\hline
\end{tabular}

\section{Discussion}

\section{Antioxidant evaluations}

Antioxidant activity depends on the structure of the compounds; some compounds have very poor antioxidant even they are in the purest form. Based from the summary of the IC50 value (Table 4) above, it can be seen that pure ascorbic acid has the lowest $\mathrm{IC}_{50}$ value of 3.876 and can be categorized as very strong antioxidant strength. This is because the ascorbic acid has its own and unique structure. A compound is said to be antioxidant is very strong if it has a value $\mathrm{IC}_{50}$ less than $50 \mathrm{~g} / \mathrm{mL}$, strong for $\mathrm{IC}_{50}$ between $50-100 \mathrm{~g} / \mathrm{mL}$, while if $\mathrm{IC}_{50}$ is $100-150 \mathrm{~g} / \mathrm{mL}$ and weak if $\mathrm{IC}_{50}$ value $150-200 \mathrm{~g} / \mathrm{mL} .^{8}$

In Table 4, it can be seen that antioxidant activity is varied from one substance to others. The pure seaweed has a lower $\mathrm{IC}_{50}$ value than yogurt, or it can be said that seaweed has better antioxidant activity when compared to yogurt. The $\mathrm{IC}_{50}$ value of yogurt is 15.548 and the $\mathrm{IC}_{50}$ value of seaweed is 11.971 , while both still are categorized as antioxidants with very strong strength.

Between the formulations, each formula has an $\mathrm{IC}_{50}$ value that varies significantly, this can be caused because the preparation contains additional substances such as PVA, PVP which may affect the absorbance. Formula 1 (F1) contains $4 \%$ yogurt and has an $\mathrm{IC}_{50}$ value of 79.422 which can be categorized as strong antioxidant. In previous studies, which also similar, made yogurt from various species of bacteria, the yogurt can inhibit the growth of "bad" bacteria $B$ subtilis and $E$ coli. ${ }^{6}$ The bacteria used was similar which were Lactobacillus bulgaricus, Streptococcus thermophilus and Lactobacillus acidophilus.

Formula 2 (F2) contains 4\% seaweed and has an $\mathrm{IC}_{50}$ value of 51.110 and is categorized as a strong antioxidant. In previous studies, which study mask from just seaweed jelly, the mask can reduce the appereance of aging spot in human $\operatorname{skin}^{3}$ perhaps because the antioxidant level of seaweed is high. On other previous studies, which exactly same material and method used, peel off gel mask from seaweed jelly has moderate antioxidant level. ${ }^{5}$ It used DPPH also as material and Vitamin $\mathrm{C}$ as an antioxidant standard,

Formula 3 (F3) contains 3\% yogurt and 1\% seaweed which has $\mathrm{IC}_{50}$ value 104.803 which can be categorized as moderate strength antioxidant. In F4 there was $2 \%$ yogurt and $2 \%$ seaweed where this formula has low $\mathrm{IC}_{50}$ value or can be said high antioxidant activity. The $\mathrm{IC}_{50} \mathrm{~F} 4$ value is 18.647 and can be categorized as an antioxidant with very strong strength and the highest antioxidant level of all formulas. Then in F5 there was of 1\% yogurt and 3\% seaweed which has an $\mathrm{IC}_{50}$ value of 22,477 where this value can be categorized as very strong antioxidant activity. The strongest antioxidant activity is in F4 which contains the same amount of yogurt and seaweed, this is likely to happen because the same amount of active substances can cause synergistic antioxidant activity between the two active substances with the appropriate concentration. 


\section{Dispersion evaluations}

Based on the results of data processing with the One-way ANOVA test, it can be said that there is a significant difference from the data of the dispersion evaluation test that has been carried out. From the data obtained, there is an increase and decrease in the spread of power measurements every week. Formula 2 (F2) has the lowest dispersion measure, and then F5, F4, F2 and the highest is F1. This can be caused because F2 contains seaweed with the largest concentration of $4 \%$. The dispersion value of all formulations has met the requirements for the dispersion value of $5-7 \mathrm{~cm}$.

Based on the results of data processing with the One-way ANOVA test, it can be said that there is a significant difference from the dispertion evaluation test data that has been carried out. From the observation data for 28 days, there was an increase and decrease in the length of time the preparations dried. However, all time data from all formulations still included in the dry time test range, which was 15-30 minutes.

\section{$\mathrm{pH}$ evaluations}

Based on the results of data processing with the One-way ANOVA test, it can be said that there is a significant difference from the data of the $\mathrm{pH}$ evaluation test that has been carried out. It can be seen that there is an increase and decrease in $\mathrm{pH}$ in each formula. However, when compared to the $\mathrm{pH}$ value of each formula, formula 1 (F1) has the lowest $\mathrm{pH}$ value among other formulas. This can be due to the fact that this formula contains yogurt with the greatest concentration of $4 \%$, considering that the $\mathrm{pH}$ of the yogurt itself is 3.85 , where the $\mathrm{pH}$ is categorized as low $\mathrm{pH}$. The opposite is seen in Formula 2 (F2) where $\mathrm{pH} \mathrm{F} 2$ is the highest $\mathrm{pH}$. This is because at F2 contains the active substance of seaweed with the largest concentration of $4 \%$, given that the $\mathrm{pH}$ of the seaweed itself is 6.08 . However, even though the $\mathrm{pH}$ value of each preparation has increased and decreased every week, the $\mathrm{pH}$ of the preparation of each formula is still within the skin $\mathrm{pH}$ range, which is in the range between 4.5-6.5.

\section{Viscosity evaluation}

Based on the results of data processing with the One-way ANOVA test, it can be said that there is a significant difference from the viscosity evaluation test data that has been carried out. From the observational data obtained, there was an increase and decrease in the viscosity value of each formulation. When viewed from the magnitude of the viscosity value, Formulation 2 (F2) has the highest viscosity value among all formulations. This can be caused because the formulation contains seaweed with the highest concentration of $4 \%$. Seaweed has a very thick consistency compared to yogurt. Therefore, of all formulations, the higher the concentration of seaweed, the greater the viscosity value. From all formulation data, the viscosity value is still within the viscosity requirement range for the peel-off gel mask preparation, which is $6000-24.000 \mathrm{cps}$.

\section{Conclusions}

a. Peel-off gel mask made from active ingredients of yogurt and seaweed has very high antioxidants,

b. The best concentration comparison between yogurt and seaweed for peel off gel is $1: 1$,

c. The peel off gel mask is convenient for consumers to use; this can be seen from the preference test.

\section{Acknowledgments}

Thank you for Institute for Research and Community Service (LPPM BKU) whom has funded this research in 2021. Bhakti Kencana University, Address Jalan Soekarno Hatta no 754, West Java, Indonesia 40617.

\section{Conflicts of interest}

Authors declare that there is no conflict of interest.

\section{References}

1. Sari AN. Alternative antioxidants to ward off the dangers of free radicals on the skin. Journal of Islamic Scienc and Technology. 2015;1(1):63-68.

2. Sumiyati Mandike SG. Peel off Gel Mask Formulation from Kepok Banana Peel (Musa paradisiaca L.). Jurnal Dunia Farmasi. 2017;1(3):123-133.

3. Anindita. Natural mask formulation made from seaweed and chocolate reduces wrinkles and blemishes on facial skin. Jurnal Care. 2017;5(2):393-402.

4. Zulkarnain I, Pakki E, Rizki Talib A. Evaluation of pharmaceutical stability and irritation test of lemon juice (citrus limon L.) mask formula with plain yogurt. As-Syifaa. 2018;10(02):239.

5. Luthfiyana N, Nurhikma N, Hidayat T. Characteristics of Peel Off Gel Mask From Seaweed (Eucheuma cottonii) Porridge. Jurnal Pengolahan Hasil Perikanan Indonesia. 2019;22(1):119.

6. Kamara DS, Rachman SD, Pasisca RW, et al. Production and Antibacterial Activity of Yogurt Fermented by Three Bacteria (Lactobacillus Bulgaricus, Streptococcus Thermophilus, Lactobacilus Acidophilus). AlKimia. 2016;4(2):22-32.

7. Widyasanti A, Rohdiana D, Ekatama N. Antioxidant Activities of White Tea Extract ( Camellia sinensis ) Using DPPH ( 2,2 diphenyl-1picrylhydrazyl ) Method. Fortech. 2016;1(1):1-9.

8. Molyneux P. The use of stable free radical diphenylpicrylhydrazyl (DPPH) for estimating antioxidant activity. Journal of Sciences and Technology. 2004;26(2):211-219. 